\section{AUTHORS:}

S'busiso M. Nkosi ${ }^{1}$ iD

Inikile Lupuleza ${ }^{1}$ id

Siyanda N. Sithole

Zenzile R. Zelda²

Anthony N. Matheri² iD

\section{AFFILIATIONS:}

${ }^{1}$ Technology Station in Chemicals,

Mangosuthu University of

Technology, Durban, South Africa

2Process, Energy and Environmenta

Technology Station, University of

Johannesburg, Johannesburg, South Africa

\section{CORRESPONDENCE TO:}

S'busiso Nkosi

\section{EMAIL:}

nkosis@mut.ac.za

DATES:

Received: 04 Mar. 2021

Revised: 25 June 2021

Accepted: 28 June 2021

Published: 29 Nov. 2021

\section{HOW TO CITE:}

Nkosi SM, Lupuleza I, Sithole SN, Zelda ZR, Matheri AN. Renewable energy potential of anaerobic mono- and co-digestion of chicken manure, goat manure, potato peels and maize pap in South Africa. S Afr J Sci. 2021;117(11/12), Art. \#10362. https://doi.org/10.17159/ sajs.2021/10362

\section{ARTICLE INCLUDES:}

囚 Peer review

$\square$ Supplementary material

\section{DATA AVAILABILITY:}

$\square$ Open data set

冈 All data included

$\square$ On request from author(s)

$\square$ Not available

$\square$ Not applicable

\section{EDITORS:}

Teresa Coutinho (iD

Salmina Mokgehle (iD

\section{KEYWORDS:}

anaerobic digestion, biomass, biomethane potential, energy mix, environment, renewable energy

FUNDING:

Mangosuthu University of Technology, University of Johannesburg, Technology Innovation Agency (South Africa)

\title{
Renewable energy potential of anaerobic mono- and co-digestion of chicken manure, goat manure, potato peels and maize pap in South Africa
}

\begin{abstract}
The energy sector is an essential part of a country's economy - it drives innovation and advances industrialisation. Coal is the primary source of energy in South Africa. Coal contributes $95 \%$ of energy production; coal-fired power also contributes to greenhouse gas emissions, and is thus a hazard to human health and the environment. This calls for an energy mix that is renewable, sustainable, and affordable and that is carbon neutral (climate action). We investigated the potential of anaerobic monoand co-digestion of goat manure, chicken manure, potato peels, maize pap, and cow manure inoculum for mesophilic recovery of renewable energy using the biomethane potential test. The substrates were characterised through proximate and ultimate analyses to determine the composition preferable for mono- and co-digestion. The key considerations in the determination of both the yield and production rate of methane from digestion of biomass are the substrate composition and characterisation. A high percentage of volatile solids favoured optimum biomethane production as highly volatile components provide microbes with balanced nutrients that enhance metabolic processes to produce biomethane. The mono-digestion process produced lower biomethane than did co-digestion. Higher production of biomethane by co-digestion was due to the balance of the micronutrients and macronutrients that favoured microbial metabolism and regulation of $\mathrm{pH}$.
\end{abstract}

\section{Significance:}

- The results highlight the need for appropriate techniques in combining energy and waste management. Biogas could provide solutions for some of South Africa's energy necessities, particularly in rural areas that have abundant biogas substrates in the form of waste from goats and chickens, as well as from kitchen waste.

\section{Introduction}

South Africa is fortunate to have an abundance of assorted energy resources that are yet to be exploited and contribute to the energy mix. The primary sources of renewable energy are solar, wind, hydro, and biomass. ${ }^{1}$ Renewable energy is taking its rightful place in the South African energy sector and playing a significant role in contributing towards sustainable development. ${ }^{2}$ South Africa is ranked as the sixth highest contributor to greenhouse gas emissions worldwide. Carbon dioxide emission per capita is $77 \%$ of the total emission in the country. In accordance with the European Union's Renewable Energy Directive ${ }^{3}$, energy generation from renewable sources is deemed to be a necessary target for reducing the impact of greenhouse gases, in particular fossil fuel combustion ${ }^{4}$. Negative health impacts and environmental degradation are driving the country's drive towards policies that are in line with Sustainable Development Goals 7 (Affordable and Clean Energy) and 13 (Climate Action).

\section{Biomass and anaerobic digestion}

Biomass is currently one of the country's main contributors to renewable energy, with 9-14\% of the overall energy mix. ${ }^{5}$ Production of energy by anaerobic digestion can be a noble resource channel if appropriately harnessed, as in the case of China and India. Renewable energy provides an easily accessible alternative for rural areas that are off the grid and have decentralised production capabilities. By contrast, anaerobic digestion is a viable technology for the production of biogas derived from organic waste. Anaerobic digestion treatment of organic feedstock to produce biogas offers a two-pronged solution to biomass waste management: generating energy and simultaneously solving the ecological and agrochemical problem. Anaerobic digestion technologies can be divided into three major groups based on the substrate's total solids (TS) content: wet anaerobic digestion with TS less than $15 \%$, dry anaerobic digestion with TS less than $25 \%$, and solid-state anaerobic digestion with TS content of up to $40 \%{ }^{6}$ In an anaerobic environment, symbiotic microorganisms convert organic matter into biogas, a constituent mixture of methane $\left(\mathrm{CH}_{4}\right)$ and carbon dioxide $\left(\mathrm{CO}_{2}\right)$ together with some nutrients, digestion-resilient organic materials and other cell components like salts. This is a four-stage process: hydrolysis, acid-genesis and acetogenesis are induced by a specific consortium of bacteria, with the final step of methanogenesis undertaken by a consortium of methanogenic archaea (Figure 1). ${ }^{6}$

\section{Anaerobic co-digestion}

Additionally, anaerobic co-digestion entails two or more feedstocks being digested simultaneously. This is a sustainable and economically viable option which results in higher yields of methane with added advantages of minimising the challenges associated with mono-digestion. Problems with anaerobic digestion, such as the presence of hazardous materials, unbalanced nutrients or obstinate compounds in the substrate, have rendered anaerobic co-digestion of multi-substrate a common field of research in the advancement and upgrade of conventional anaerobic digestion technology. Work on anaerobic co-digestion has grown dramatically over the last 15 years, demonstrating its capacity to make progress in the production of biogas. ${ }^{7-10}$ 


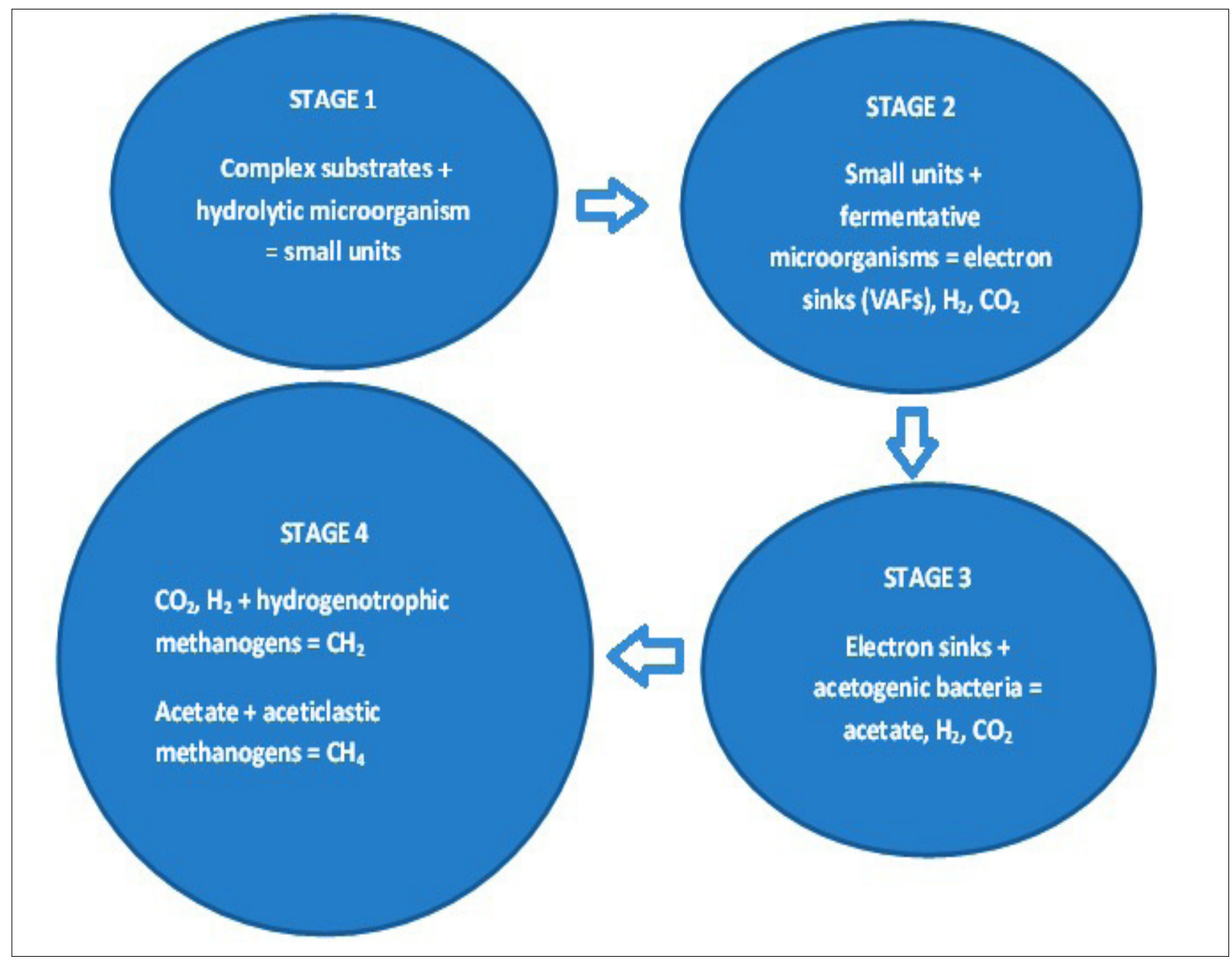

VAF, volatile fatty acids

Figure 1: A schematic of the microbial processes involved in anaerobic digestion.

The main objective of anaerobic co-digestion is to increase methane for renewable energies. As shown in Figure 2, a variety of substrates can be co-digested by blending into different ratios and maintaining optimum conditions needed for the metabolic activities and improvement in the biogas production.

Unlike wastewater, the solid feedstock contains high levels of insoluble organic matter and chemical oxygen demand. These organic matters can be recycled to provide bioenergy. Animal manure is an organic product that is used in horticulture and agriculture as a natural fertiliser. It is a combination of faeces, urine and products that may be used in waste control, such as grass, sand, washing water and other bedding products. ${ }^{11}$ Animal manure from livestock farming has been customarily reused as organic fertiliser for the provision of nitrogen and phosphorus for crops and plants. However, the environment was negatively impacted due to increased concentrations of carbon and discharge of soluble phosphorus and nitrogen. Animal manure from dairy cattle ${ }^{12}$ and buffalo farming ${ }^{13}$ produces large quantities of greenhouse gases, second only to enteric methane. Furthermore, manure generates volatilised ammonia that is up to $70 \%$ of the excreted residual nitrogen which enters water systems and natural ecosystems or contributes to climate change and eutrophication through conversion into $\mathrm{N}_{2} \mathrm{O}$ emissions. ${ }^{14}$

Goat manure is commonly found in South Africa. It is an excellent substrate for anaerobic digestion due to its optimum range of $\mathrm{C} / \mathrm{N}$ ratio and robustness of growth. The amount of manure produced by a goat with a typical body weight of $20-40 \mathrm{~kg}$ is approximately $0.32-$ $0.63 \mathrm{~kg} /$ day, which is comparable to approximately 0.3 tons/year. ${ }^{15}$ For instance, a nation with around 1 million goats is estimated to produce approximately 0.3 million tons of organic fertiliser per year.

Chicken manure is a semi-solid biodegradable material. Therefore, it can be used to generate cheap energy. ${ }^{16}$ Fresh chicken manure contains $0.4-0.5 \%$ phosphorus, $0.8 \%$ potassium and $0.9-1.5 \%$ nitrogen. It has been reported that the daily production of chicken manure varies from $80 \mathrm{~g}$ to $125 \mathrm{~g}$ (wet), of which $20-25 \%$ of the production comprises total nitrogen-rich solids and $55-65 \%$ contains volatile solids (VS) which are a valuable energy source. ${ }^{17}$ However, the higher content of nitrogen in chicken manure compared with that in manure from other farm animals (i.e. cattle, pig, horse, goat, sheep, and rabbit) ${ }^{18-26}$ makes it unsuitable for the anaerobic digestion process ${ }^{27}$ Ammonia inhibition is one of the common problems with the anaerobic digestion process when using substrates like poultry manure ${ }^{28}$ and pig manure ${ }^{29}$. The inhibitory impacts of free ammonia on the methanogen's digestive mechanism was observed by Zhang et al. ${ }^{30}$ In general, one of the tricks to avoid ammonia inhibition is to dilute the chicken manure with water $^{31}$, which assists in decreasing the high percentage of TS. This dilution step is said to reduce the production of biogas per unit of fermenter volume, increase the use of water and increase the processing costs for the slurry discharge. Several researchers have assessed the co-digestion of chicken manure with other animal manures such as cow manure ${ }^{32}$ or pig manure ${ }^{33}$, or with other substrates, such as potato peels ${ }^{34}$.

Leftover, lost or uneaten food is food waste and can originate throughout the entire food supply chain. This value chain starts from preparation to production, processing, delivery, storage and sale to cooking and presentation. ${ }^{35}$ Consumer stage food waste from restaurants, homes, schools, and hospital cafeterias is usually targeted. ${ }^{36}$ 


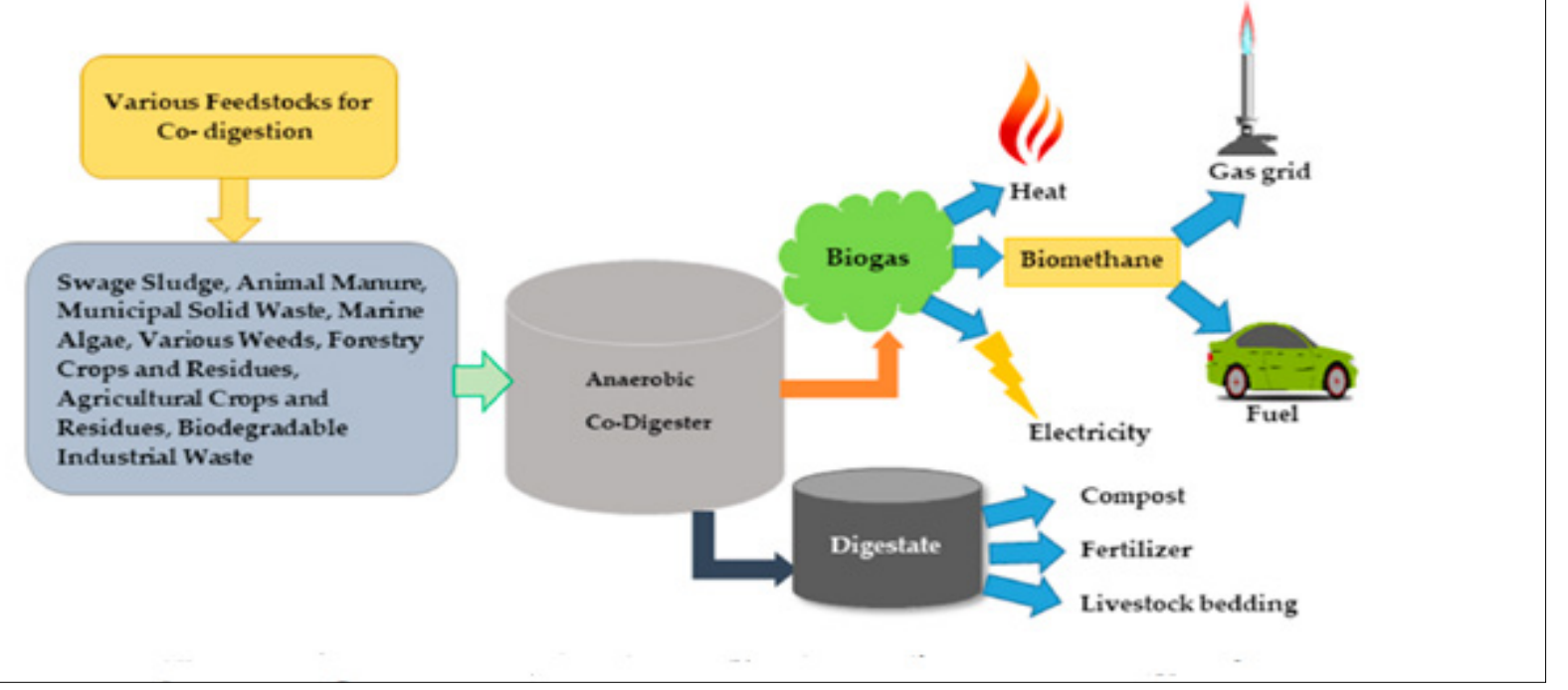

Figure 2: A diagram of multi-feedstock co-digestion in energy recovery.

Developing countries generally have scant information with regard to food wastage. Food wastage is globally reported to be higher in developed than in developing countries. ${ }^{37,38}$ An annual per capita average of food waste in developed countries ranges from $100 \mathrm{~kg}$ to $170 \mathrm{~kg}$, which is double that of developing countries. ${ }^{39} \mathrm{~A}$ few developing countries, including India and China, are considered to have greater challenges in food waste disposal despite the broad total population. ${ }^{39}$ More than $40 \%$ of the food (about 222 million tons) is lost or wasted in the retail pathway and consumer stages in developed countries, which is nearly as high as the total net food production in sub-Saharan Africa (230 million tons). ${ }^{39}$ Although anaerobic digestion technology is a well-known technology for energy recovery, there are still unaddressed issues related to economic and environmental concerns, food security, technology choice, organic loading rates, nature of substrates, parameters variation in different locations globally, disposal of digestate after digestion, and mitigation to climate change. ${ }^{40,41}$ In the present study, we investigated the potential of anaerobic mono- and co-digestion of potato peels, maize pap, chicken manure, and goat manure for renewable energy recovery.

\section{Methodology \\ Substrate quantification}

Food waste was collected from the cafeteria and animal manure samples were collected from the Department of Agriculture farm of the Mangosuthu University of Technology (KwaZulu-Natal Province, South Africa). Samples were collected into 5-L plastic containers, closed airtight, and stored at $4{ }^{\circ} \mathrm{C}$ in the refrigerator. The samples were labelled as chicken manure, goat manure, potato peels, maize pap, and inoculum from the cow manure. To pre-treat the samples and minimise the maturing effect, as well as to limit the microbial activities, the feedstock was dried in the oven at $60^{\circ} \mathrm{C}$, reduced to a 2-mm size diameter, and stored in the fridge at $4{ }^{\circ} \mathrm{C}$ until utilised. The inoculum was prepared by digesting cow dung samples until no biogas was produced. This was done in order to ensure that the microorganisms digest all the substrate in cow dung completely before adding new substrate to ensure that biogas produced was from new substrate and not from substrate in the cow dung. The retention time for the inoculum preparation was 14 days.

\section{Experimental procedure}

The biomethane production rate was determined by feeding the substrates and the inoculum into a batch digester. Chicken manure, goat manure, potato peels, maize pap, and inoculum of cow manure were fed as a mono-substrate for mono-digestion. Chicken manure and potato peels, chicken manure and pap, goat manure and potato peels, goat manure and maize pap, maize pap and potato peels, and a mix of chicken manure, potato peels, goat manure and maize pap were codigested in the ratio of 1:1. The substrates were fed with the control. The conditions were set at mesophilic temperatures of $37^{\circ} \mathrm{C}$ and the working $\mathrm{pH}$ of 6.5-7.5 was adjusted using sodium hydroxide and sulfuric acid. A bioprocess controller (AMPTS II) by Dürr Systems, Inc. (De Pere, WI, USA) was used to perform the biomethane potential test. The AMPTS II consisted of an automated digester, $\mathrm{CO}_{2}$ fixing unit, and biomethane collection unit. Bioreactors with a volume of $500 \mathrm{~mL}$ and a headspace of $100 \mathrm{~mL}$ were used. Sodium hydroxide was used to remove $\mathrm{CO}_{2}$ from the production of biogas to biomethane. A 3-M sodium hydroxide solution was used to remove $\mathrm{CO}_{2}$ and $\mathrm{H}_{2} \mathrm{~S}$. A pH indicator solution with $0.4 \%$ thymolphthalein was applied to the sodium hydroxide solution where the $\mathrm{pH}$ indicator was used as a scrubber. Before preparing the substrates and feeding into the digesters, the prepared $\mathrm{NaOH}$ with $\mathrm{pH}$ indicator was used to determine the saturation point for the cleaning solution to be replaced. Thus, the digesters were purged with nitrogen gas to create an anaerobic state by discharging the oxygen. The gas that exited the $\mathrm{CO}_{2}$ fixing unit was sent to the stream cell (gas collection unit) and assessed on a daily basis using water downward displacement technique until the retention time was completed. Figure 3 shows the bioprocess controller (AMPTS II).

\section{Analytical techniques}

\section{Proximate analysis}

The chemical and physical compositions, moisture content, total solids (TS), volatile solids (VS), and hydrogen potential $(\mathrm{pH})$ were calculated using standard methods (APHA 1995). ${ }^{42}$

\section{Ultimate analysis}

A Flash 2000 CHNS-0 element analyser (Thermo Fisher Scientific Inc., Waltham, MA, USA) fitted with an autosampler was used to analyse the elemental (C, H, N, S) composition of the substrate. In replicates per sample, a dry mass of $1 \mathrm{mg}$ of each substratum was weighed into a tin capsule. CHNS was then determined by an autosampler by placing the samples in an electrolyte-filled quartz reactor and then inserting them into the reactor cell. After combustion in an oxygen-rich environment, the gases given off were carried by a helium flow past a copper-filled layer, through a gas chromatography column where the combustion gases were separated and detected by a detector (Thermal Conductivity Detector, Waltham, MA, USA) with a column oven temperature of $65^{\circ} \mathrm{C}$ detection. 


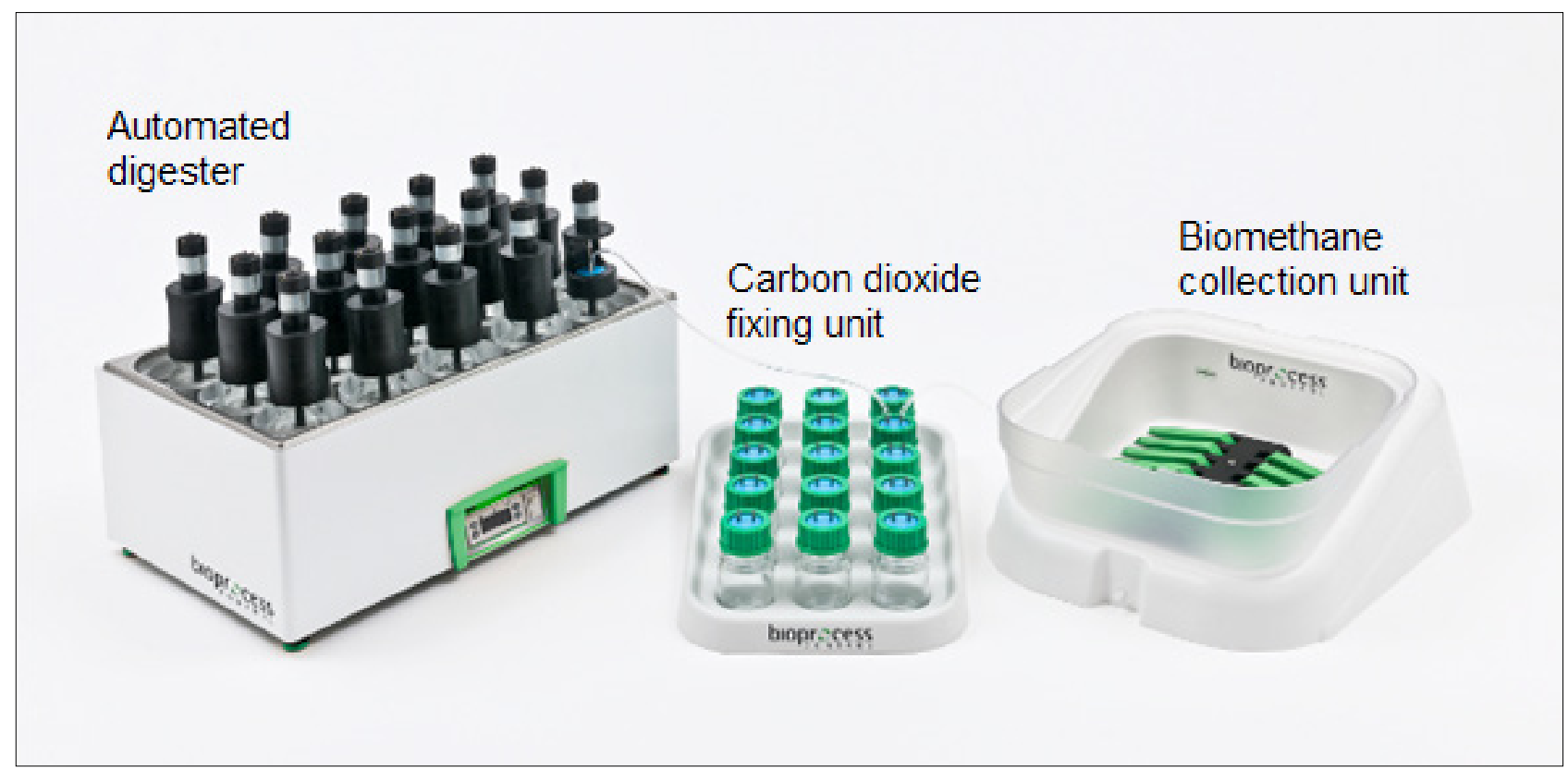

Figure 3: The bioprocess controller (AMPTS II) used to perform the biomethane potential test. The AMPTS II consisted of an automated digester, carbon dioxide fixing unit, and biomethane collection unit.

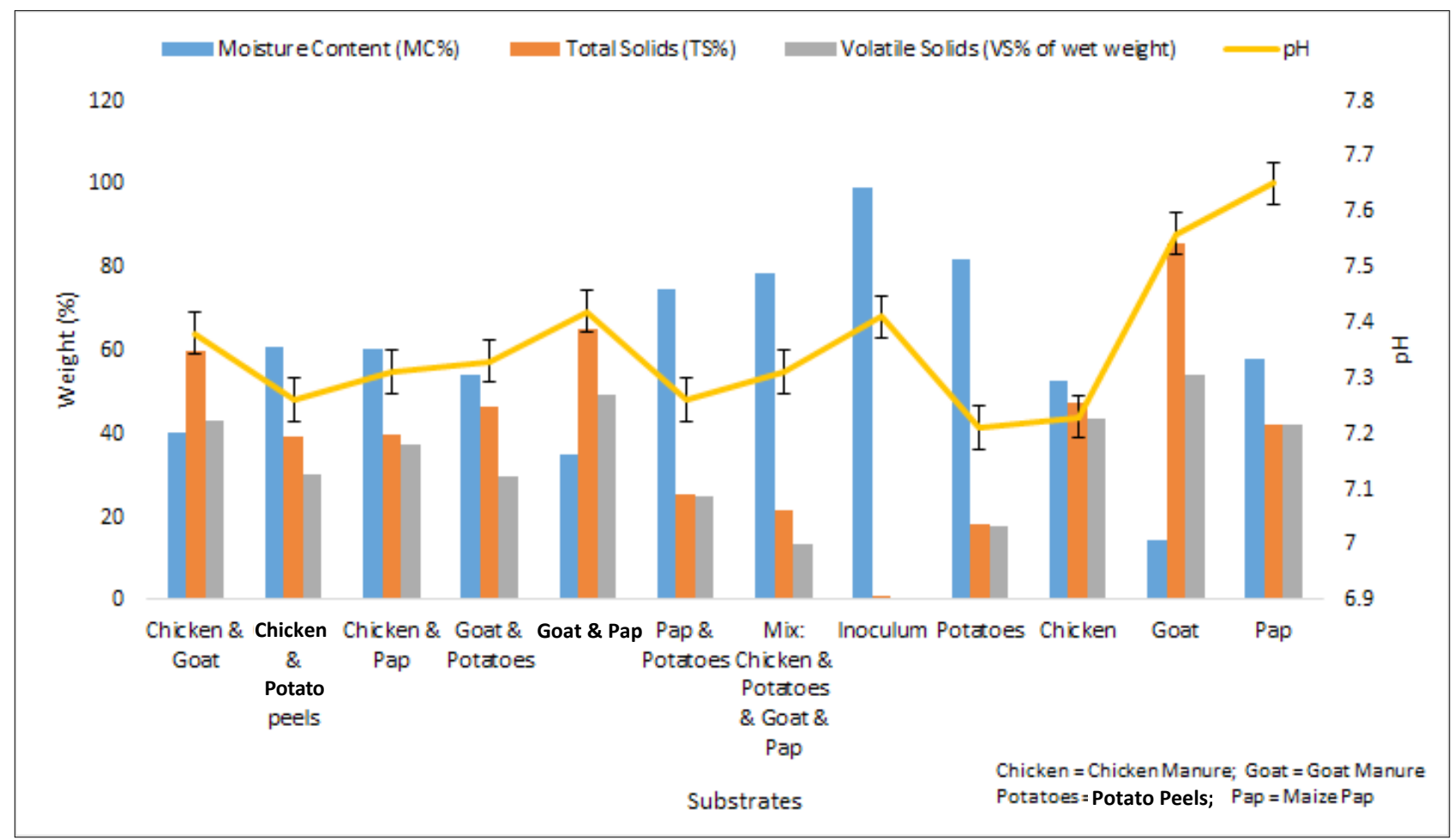

Figure 4: Results of the proximate analysis of the substrates and absolute $\mathrm{pH}$ on biogas accumulation.

\section{Results and discussion \\ Characterisation of substrate}

\section{Proximate analysis}

Characteristics of the mono-substrates chicken manure (CM), goat manure (GM), potato peels (PP), maize pap (MP) and inoculum cosubstrates $\mathrm{CM}+\mathrm{GM}, \mathrm{CM}+\mathrm{MP}, \mathrm{GM}+\mathrm{MP}, \mathrm{CM}+\mathrm{PP}, \mathrm{GM}+\mathrm{PP}, \mathrm{MP}+$ $\mathrm{PP}$ are shown in Figure 4. Substrate composition and characterisation can be a major factor in deciding the levels of methane production and methane generation from biomass digestion. VS are the organic component of TS that biodegrade, where TS is the total amount of suspended solids and dissolved solids. Optimum production of biomethane is attained when the \%VS is low, as this helps bacteria to provide volatile compounds with methane and metabolic processes. VS therefore play an important role in optimal digestion, because they allow the digestion process to generate high-quality biomethane. 
Goat manure and chicken manure had a \%VS of $43.46 \%$ and $54.28 \%$, respectively. These values indicate a good potential to convert biosolid to bioenergy. The inoculum had lower VS due to initial digestion during the preparation. Potato peels had the highest moisture content in the composition. Due to variation in composition, this called for codigestion of samples to reach the optimum range for the digestion of substrate to energy (biomethane). The VS/TS ratios for mono-substrates were $63.52 \%, 91.45 \%, 99.76 \%$ and $96.61 \%$ for GM, CM, MP and PP, respectively. The higher the VS/TS ratio, the higher the organic content, which is favourable for the production of biomethane.

\section{Ultimate analysis}

The $\mathrm{C} / \mathrm{N}$ ratio was imperative in the microscopic organism's stability within the anaerobic process. However, examination of the organic components showed that $\mathrm{CM}, \mathrm{PP}$, and MP had $\mathrm{C} / \mathrm{N}$ ratios of $42.91 \%$, $99.70 \%$ and $37.30 \%$, respectively, which are unsuitable for anaerobic digestion and out of range of the optimum (10 to 30$) \mathrm{C} / \mathrm{N}$ ratio. ${ }^{42,43}$ However, GM had a C/N ratio of 20.47, which is within the optimum range. A high $\mathrm{C} / \mathrm{N}$ ratio leads to a deficiency within the anaerobic digestion system due to the methanogens' fast nitrogen consumption leading to lower gas production. A lower $\mathrm{C} / \mathrm{N}$ ratio indicates high nitrogen that can transform into ammonia. Ammonia inhibits the microbes' activities. Codigestion enhanced the nutrient balance of the substrates and provided an optimal $\mathrm{C} / \mathrm{N}$ range. Figure 5 shows the results of the ultimate analysis of the mono-substrates.

\section{Biomethane potential test of biomass}

\section{Mono-digestion of biomass}

The biomethane potential test was vital in assessing the biomethane production of the respective organic feedstock amid its anaerobic deterioration. Figure 6 shows the biomethane production from the monodigestion of substrates.

The retention time for substrate digestion to yield biomethane was 21 days. The organic loading rate ratio of substrate to inoculum was $1: 2$ of \%VS. It was observed that the inoculum produced lower methane than did the other substrates because it was previously digested for
14 days and the nutrients were exhausted. Maize pap produced the most methane (1650.8 NmL CH$/ \mathrm{g} \mathrm{VS}$ ) because of the high nutrient composition and balance. Carbohydrates are generally considered to be rapidly degradable. The shortest lag phase as observed in Figure 6 was due to the introduction of inoculum that supplied microorganisms. Within 8 days, the production of biomethane was at equilibrium due to the rapid aggregation of unstable greasy acids that led to a reduction in biomethane production. Lower production of the biomethane was attributed to lower growth and metabolism of the methanogens due to poor nutritional structure $(\mathrm{C} / \mathrm{N}$ ratio) and insufficient micronutrients. PP, GM, and CM produced 1423.6, 726.9, and $120.7 \mathrm{NmL} \mathrm{CH}_{4} / \mathrm{g}$ VS, respectively.

\section{Co-digestion of biomass}

Figure 7 shows the biomethane production from the co-digestion of substrates. It was observed that most of the highest biomethane accumulation was achieved within the initial 9 days of retention time for all the co-digested substrates except for MP and PP. After the ninth day, all production became steady and reached equilibrium for the remainder of the 21 experimental days. The highest biomethane production of $1332.2 \mathrm{NmL} \mathrm{CH}_{4} / \mathrm{g}$ VS was achieved for GD and PP substrates. This was due to the availability and balance of nutrients, and microbial balance. The CM and MP substrates recorded the lowest biomethane potential of $474.6 \mathrm{NmL} \mathrm{CH} / \mathrm{g}$ VS. In the anaerobic digestion process, a synergistically decomposition of organic matter caused a bacterial consortium generating biogas and biomethane. Inhibition in some substrates occurred because of imbalanced rates between hydrolysis and methanogenesis. It was necessary to have a suitable balance between those levels to obtain higher biomethane production. A rapid pathway for methanogenesis was necessary to prevent the over accumulation of the organic acid and reduction in $\mathrm{pH}$, as well as high ammonia and an increase in $\mathrm{pH}$ to a degree that would inhibit methanogenesis. For the production of methane-forming microbes, certain nutrient components are required. ${ }^{44}$ Relevant trace elements such as nickel, cobalt, iron and molybdenum are important for the ideal development and production of biomethane because they stimulate methanogenic activity.

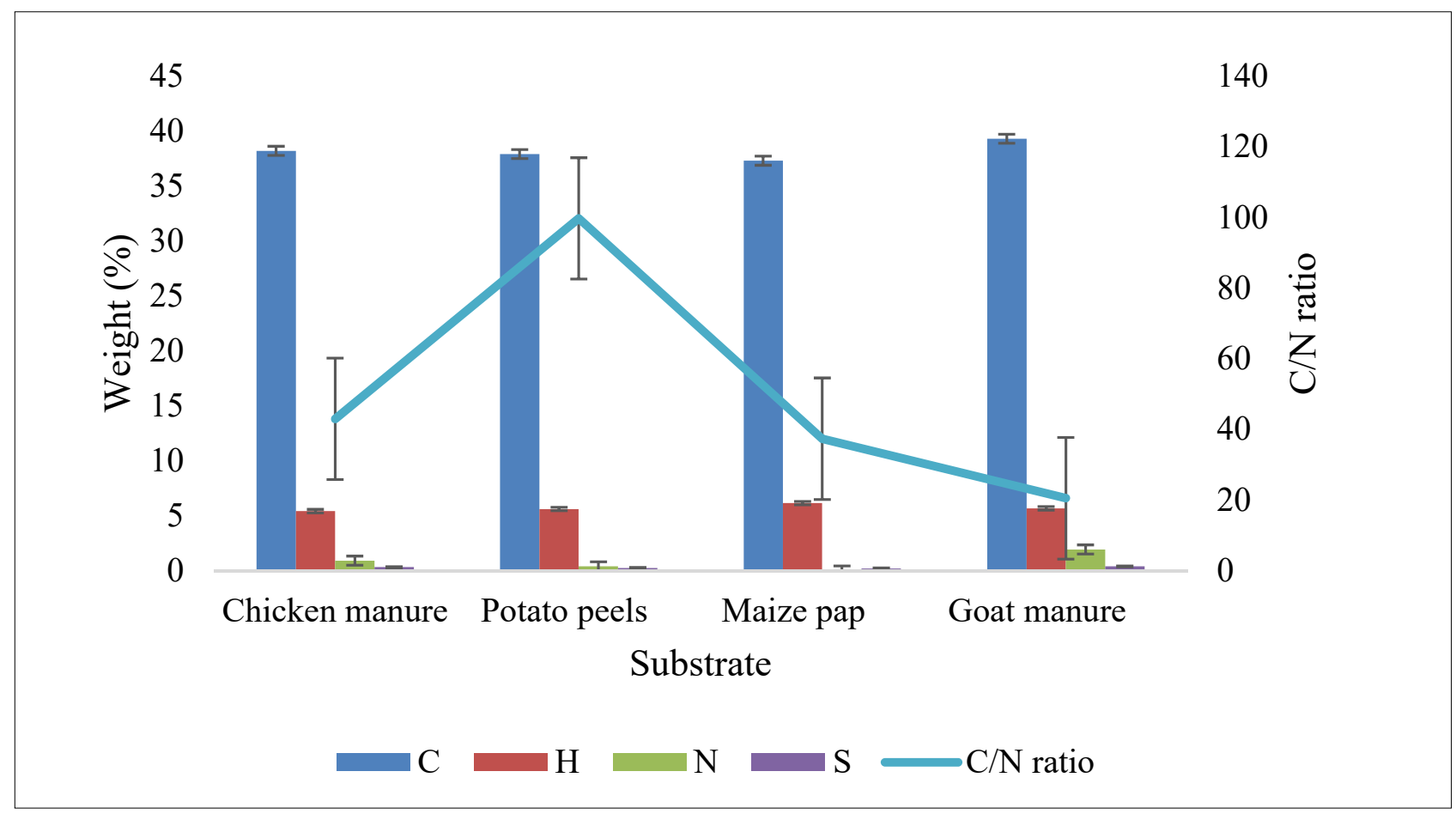

Figure 5: Results of the ultimate analysis of the substrates. 


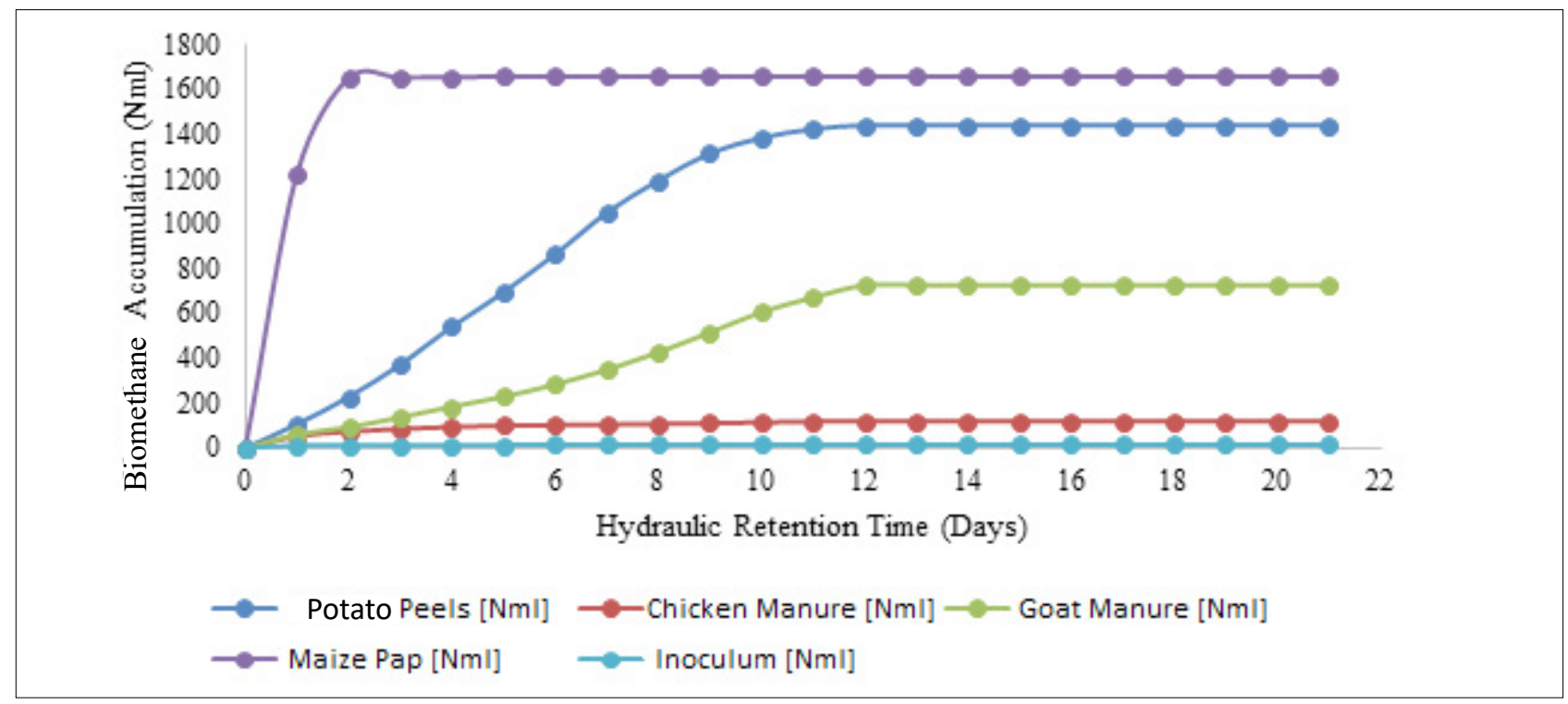

Figure 6: Biomethane production through mono-digestion of substrates.

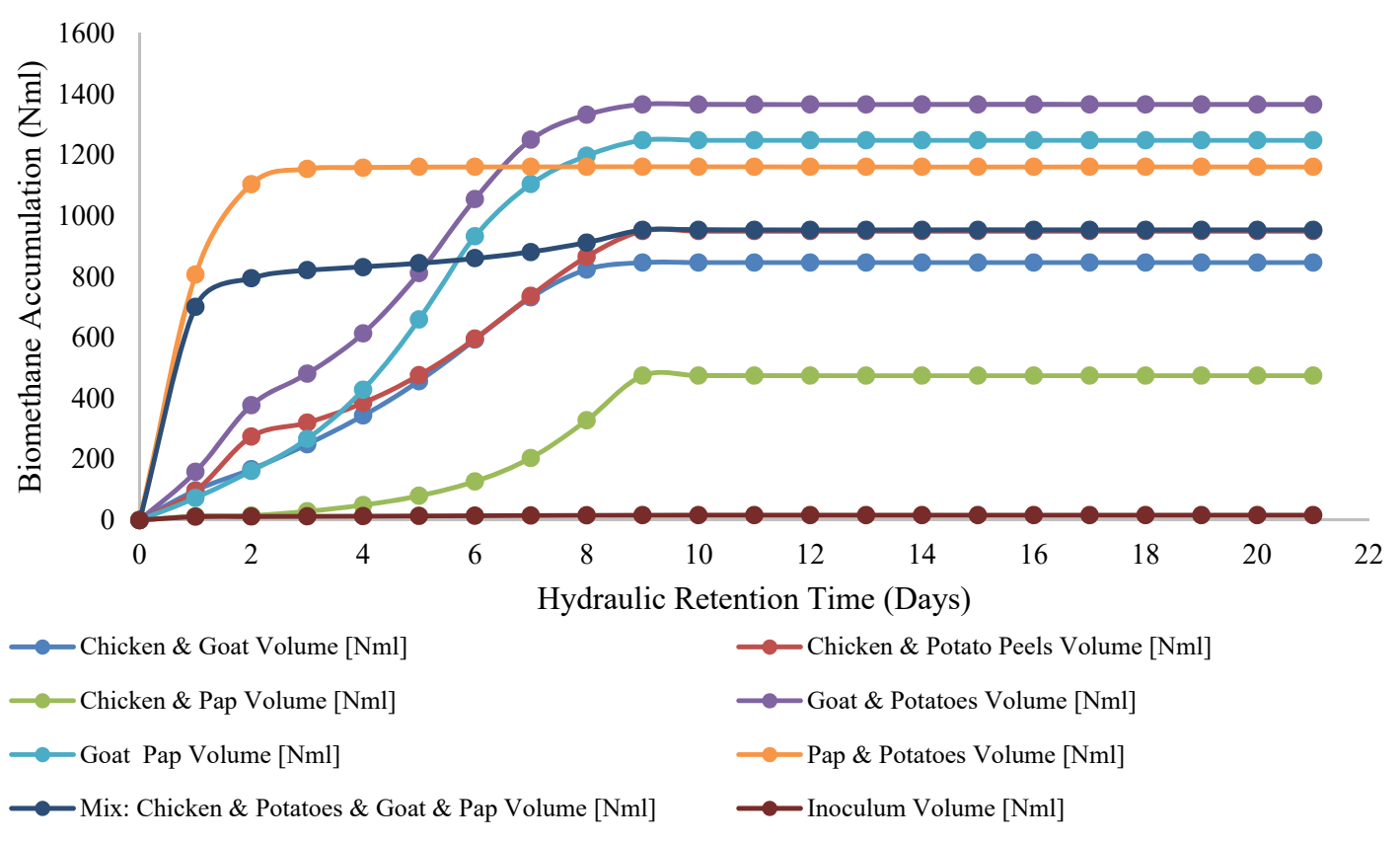

Figure 7: Biomethane production through co-digestion of substrates.

The microbial activity in biomethane development was stimulated by boron, manganese, molybdenum, aluminium and selenium in substrates. ${ }^{45-47}$ According to Duran and Speece ${ }^{48}$, the addition of metal ions to anaerobic digesters plays a key role in improving the performance of the anaerobic digestion system through co-digestion. Co-digestion of substrates enhanced nutrients to microbial balance.

The influence of $\mathrm{pH}$ on biomethane production is shown in Figure 4. The highest biomethane production of $1332.2 \mathrm{NmL} \mathrm{CH}_{4} / \mathrm{g}$ VS was observed at a pH of 7.11, whereas productions of 1248.2, 1154.2, 949.2, 846.4 and $474.6 \mathrm{NmL} \mathrm{CH}_{4} / \mathrm{g} \mathrm{VS}$ were observed at a $\mathrm{pH}$ of $5.97,7.15,7.52$ and 7.54 , respectively.

Chicken manure and potato peel substrates had lower $\mathrm{pH}$ of 7.23 and 7.21, respectively, within the range of 6.5-7.5. Goat manure and maize pap substrates had higher pH of 7.56 and 7.65 , respectively, slightly above the optimum range. Co-digestion of substrates assisted in adjusting the $\mathrm{pH}$ to 7.31 , within the optimum range. ${ }^{48-51}$

\section{Conclusions}

Volatile solids, moisture content and total solids played an important role in optimal digestion, by enabling the digestion process to generate high-quality biomethane. Goat manure and chicken manure had \%VS of $43.46 \%$ and $54.28 \%$, indicating a good potential to convert biosolids to bioenergy. Higher VS/TS ratios of the organic content enhanced higher production of biomethane. Co-digestion regulated nutrients and created a nutrient balance of the substrates that were out of the optimum range ( $\mathrm{C} / \mathrm{N}$ ratio of $10-30)$. Mono-digestion of maize pap resulted in the highest biomethane production of $1650.8 \mathrm{NmL} \mathrm{CH}_{4} / \mathrm{g}$ VS because of the high nutrient composition and balance. Co-digestion of goat manure and potato peels resulted in the highest biomethane production of 1332.2 $\mathrm{NmL} \mathrm{CH}_{4} / \mathrm{g}$ VS among the co-digested substrates. This was due to the 
nutrient and microbial balance. The anaerobic digestion process assisted in energy recovery. Co-digestion addressed issues related to economic and environmental concerns, microbial-nutrient balance, organic loading rates, regulation of parameter variation, and mitigation to climate change. Co-digestion is efficient, economically viable, produces higher yields of methane and has the ability to mitigate some of the problems that may arise from mono-digestion. The problems in anaerobic digestion - such as unbalanced nutrients, the presence of poisonous materials or persistent elements in the substrates - make co-digestion a viable technology.

\section{Acknowledgements}

We acknowledge the Technology Station in Chemicals, Mangosuthu University of Technology (Durban, South Africa), Process, Energy \& Environmental Technology Station, University of Johannesburg (Johannesburg, South Africa), and the Technology Innovation Agency for funding and knowledge transfer and Ms Xolile Veronica Ngubane and Ms Esther Nabadda for proofreading and editing the manuscript.

\section{Competing interests}

We have no competing interests to declare.

\section{Authors' contributions}

S.M.N.: Conceptualisation, methodology, sample analysis, project management, student supervision, writing - the initial draft, writing revisions, funding acquisition. I.L.: Data collection, sample analysis. S.N.S.: Data collection, sample analysis. Z.R.Z.: Project management, project leadership. A.N.M.: Methodology, writing - the initial draft, writing - revisions.

\section{References}

1. Omar A, Haitham A, Frede B. Renewable energy resources: Current status, future prospects, and their enabling technology. Renew Sustain Energy Rev. 2014;39:748-764. https://doi.org/10.1016/j.rser.2014.07.113

2. Pegels A. Renewable energy in South Africa: Potentials, barriers, and options for support. Energy Policy. 2010;38:4945-4954. https://doi.org/10.1016/j. enpol.2010.03.077

3. Directive $2009 / 28 / \mathrm{EC}$ of the European parliament and of the Council of 23 April 2009 on the promotion of the use of energy from renewable sources and amending and subsequently repealing directives 2001/77/EC and 2003/30/ EC. Brussels: European Commission; 2009.

4. Olivier JGJ, Schure KM, Peters AW. Trends in global $\mathrm{CO}_{2}$ and total greenhouse gas emissions. PBL publication number 2674. The Hague: PBL Netherlands Environmental Assessment Agency; 2017.

5. Banks D, Jason $\mathrm{S}$. The potential contribution of renewable energy in South Africa. Johannesburg: Sustainable Energy and Climate Change Project of Earthlife Africa; 2006.

6. Mamun A, Torii S. Anaerobic co-digestion technology in solid wastes treatment for biomethane generation. Int J Sustain Energy. 2015;36:462-472. https://doi.org/10.1080/14786451.2015.1043302

7. Kwietniewska E, Tys J. Process characteristics, inhibition factors, and methane yields of the anaerobic digestion process, with particular focus on microalgal biomass fermentation. Renew Sustain Energy Rev. 2014;34:491500. https://doi.org/10.1016/..rser.2014.03.041

8. Gelegenis J, Georgakakis D, Angelidaki I, Christopoulou N, Goumenaki M. Optimization of biogas production from olive-oil mill wastewater, by codigesting with diluted poultry-manure. Appl Energy. 2007;84:646-663. https://doi.org/10.1016/j.apenergy.2006.12.001

9. Karagiannidis A, Perkoulidis G. A multi-criteria ranking of different technologies for the anaerobic digestion for energy recovery of the organic fraction of municipal solid wastes. Bioresour Technol. 2009;100:2355-2360. https://doi.org/10.1016/j.biortech.2008.11.033

10. Hagos K, Zong J, Li D, Liu C, Lu X. Anaerobic co-digestion process for biogas production: Progress, challenges, and perspectives. Renew Sustain Energy Rev. 2017;76:1485-1496. https://doi.org/10.1016/.j.rser.2016.11.184
11. Rao JR, Watabe M, Stewart TA, Millar BC, Moore JE. Pelleted organo-mineral fertilizers from composted pig slurry solids, animal wastes and spent mushroom compost for amenity grassland. J Waste Manag. 2007;27:11171128. https://doi.org/10.1016/j.wasman.2006.06.010

12. Aguirre-Villegas HA, Larson R. Evaluating greenhouse gas emissions from dairy manure management practices using survey data and lifecycle tools. J Clean Prod. 2017;143:169-179. https://doi.org/10.1016/i. jclepro.2016.12.133

13. Sabia E, Napolitano F, Claps S, De Rosa G, Braghieri A, Pacelli C. Dairy buffalo life cycle assessment as affected by heifer rearing system. J Clean Prod. 2018;192:647-655. https://doi.org/10.1016/j.jclepro.2018.04.158

14. Hristov AN, Zaman S, Vander Pol M, Ndegwa P, Campbell L, Silva S. Nitrogen losses from dairy manure estimated through nitrogen mass balance and chemical markers. J Environ Qual. 2001;38:2438-2448. https://doi. org/10.2134/jeq2009.0057

15. Yadav SK, Subhash B, Yadav MK, Singh K, Yadav GS, Pal S. A review of organic farming for sustainable agriculture in northern India. Int J Agron. 2013;2013, Art. \#718145. https://doi.org/10.1155/2013/718145

16. Abouelenien F, Fujiwara W, Namba Y, Kosseva M, Nishio N, Nakashimada $Y$. Improved methane fermentation of chicken manure via ammonia removal by biogas recycle. Bioresour Technol. 2010;101:6368-6373. https://doi. org/10.1016/j.biortech.2010.03.071

17. Moral R, Moreno-Caselles J, Perez-Murcia M, Perez-Espinosa A, Rufete B, Paredes $\mathrm{C}$. Characterisation of the organic matter pool in manures. Bioresour Technol. 2005;96:153-158. https://doi.org/10.1016/..biortech.2004.05.003

18. Olowoyeye J. Comparative studies on biogas production using six different animal dungs. J Biol Agric Healthcare. 2013;3:7-12.

19. Triolo JL, Ward AJ, Pedersen L, Sommer SG. Characteristics of animal slurry as key biomass for biogas production in Denmark. In: Matovic MD, editor. Biomass now - sustainable growth and use. London: InTech; 2013.

20. Chen F, Yu G, Li W, Liu FW, Zhang WP, Bu YS, et al. Maximal methane potential of different animal manures collected in the northwest region of China. Int $J$ Agric Biol. 2017;10:202-208.

21. Buratti FC. Biogas production from different substrates in an experimenta continuously stirred tank reactor anaerobic digester. Bioresour Technol. 2009;100:5783-5789. https://doi.org/10.1016/j.biortech.2009.06.013

22. Pham CH, Triolo JM, Cu TTT, Pedersen L, Sommer SG. Validation and recommendation of methods to measure biogas production potential of animal manure. Asian Australas J Anim Sci. 2013;26:864-873. https://doi. org/10.5713/ajas.2012.12623

23. Andrade WR, Xavier CAN, Coca FG, Arruda LDO, Santos TMB, Biogas production from ruminant and monogastric animal manure co-digested with manipueira. Arch de Zootec. 2016;65:251-380. https://doi.org/10.21071/ az.v65i251.699

24. Kafle GK, Chen L. Comparison on batch anaerobic digestion of five different livestock manures and prediction of biochemical methane potential (BMP) using different statistical models. J Waste Manag. 2016:48:492-502. https:// doi.org/10.1016/j.wasman.2015.10.021

25. Budiyono B, Widiasa IN, Johari S, Sunarso S. Increasing biogas production rate from cattle manure using rumen fluid as inoculums Int J Eng Sci. 2014;6:31-38. https://doi.org/10.12777/ijse.6.1.31-38

26. Osman GAM, Elhasan HE, Hassan AB. Effect of cow rumen fluid concentration on biogas production from goat manure. Sudan J Agric Sci. 2015;2:1-7.

27. Bujoczek G, Oleszkiewicz J, Sparling R, Cenkowski, S. High solid anaerobic digestion of chicken manure. J Agric Eng Res. 2000;76:51-60. https://doi. org/10.1006/jaer.2000.0529

28. Gangagni R, Sasi Kanth A, Reddy T, Surya Prakash S, Vanajakshi J, Joseph $\mathrm{J}$, et al. Biomethanation of poultry litter leachate in UASB reactor coupled with ammonia stripper for enhancement of overall performance. Bioresour Technol 2008;99:8679-8684. https://doi.org/10.1016/j.biortech.2008.04.016

29. Hansen KH, Angelidaki I, Ahring BK. Anaerobic digestion of swine manure: Inhibition by ammonia. Water Res. 1998:32:5-12. https://doi.org/10.1016/ S0043-1354(97)00201-7

30. Zhang C, Yuan Q, Lu Y. Inhibitory effects of ammonia on methanogen more transcripts in anaerobic digester sludge. FEMS Microbiol Ecol. 2014;87:368377. https://doi.org/10.1111/1574-6941.12229 
31. Niu Q, Qiao W, Qiang H, Li YY. Microbial community shifts and biogas conversion computation during steady, inhibited, and recovered stages of thermophilic methane fermentation on chicken manure with a wide variation of ammonia. Bioresour Technol. 2013;146:223-233. https://doi.org/10.1016/j. biortech.2013.07.038

32. Wang X, Yang G, Feng $Y$, Ren G, Han X. Optimizing feeding composition and carbon-nitrogen ratios for improved methane yield during anaerobic co-digestion of dairy, chicken manure, and wheat straw. Bioresour Technol. 2012;120:78-83. https://doi.org/10.1016/j.biortech.2012.06.058

33. Borowski S, Domanski J, Weatherley L. Anaerobic co-digestion of swine and poultry manure with municipal sewage sludge. J Waste Manag. 2014;34:513-521. https://doi.org/10.1016/j.wasman.2013.10.022

34. Ali S, Shah TA, Afzal A, Tabbassum R, Evaluating the co-digestion effects on chicken manure and rotten potatoes in batch experiments. Int J Biosci. 2017;10:150-159. https://doi.org/10.12692/ijb/10.6.150-159

35. Lin CSK, Pfaltzgraff ALA, Herrero-Davila L, Mubofu EB, Abderrahim S, Clark $\mathrm{JH}$, et al. Food waste as a valuable resource for the production of chemicals, materials, and fuels. Current situation and global perspective. Energy Environ Sci. 2013;6:426-464. https://doi.org/10.1039/c2ee23440h

36. Parfitt J, Barthel M, Macnaughton S. Food waste within food supply chains: Quantification and potential for change to 2050. Philos Trans R Soc B. 2010;365:3065-3081. https://doi.org/10.1098/rstb.2010.0126

37. United Nations. Responsible consumption and production: Why it matters [document on the Internet]. c2019 [cited 2020 May 20]. Available from: https:// www.un.org/sustainabledevelopment/wp-content/uploads/2019/07/12_ Why-It-Matters-2020.pdf

38. Dunga TN, Sena B, Chen C, Kumare G, Lina C. Food waste to bioenergy via anaerobic processes. Energy Procedia. 2014;61:307-312. https://doi. org/10.1016/j.egypro.2014.11.1113

39. Gustafson J, Cederberg C, Sonesson U, Van Otterdijk R, Meybeck A. Global food losses and food waste: Extent, causes, and prevention. Rome: Food and Agriculture Organization of the United Nations; 2011.

40. Food and Agriculture Organization of the United Nations (FAO). Global food losses and food waste [document on the Internet]. c2011 [cited 2020 May 20]. Available from: http://www.fao.org/docrep/014/mb060e/mb060e00.pdf
41. Nishio N, Nakashimada Y. Recent development of anaerobic digestion processes for energy recovery from wastes. J Biosci Bioeng. 2007;103:105112. https://doi.org/10.1263/jbb.103.105

42. Rice EW. Standard methods for the examination of water and wastewater. Vol 10. Washington DC: American Public Health Association; 2012

43. Gunaseelan VN. Biochemical methane potential of fruits and vegetable solid waste feedstocks. Biomass Bioenergy. 2004;26:389-399. https://doi. org/10.1016/j.biombioe.2003.08.006

44. Romano TT, Zhang RH. Co-digestion of onion juice and wastewater sludge using an anaerobic mixed biofilm reactor. Bioresour Technol. 2008;99:631637. https://doi.org/10.1016/j.biortech.2006.12.043

45. Montingelli ME, Tedesco S, Olabi AG. Biogas production from algal biomass: A review. Renew Sustain Energ Rev. 2015;43:961-972.

46. Karlsson A, Truong XB, Gustavsson J, Svensson BH, Nilsson F, Ejlertsson J. Anaerobic treatment of activated sludge from Swedish pulp and paper mills biogas production potential and limitations. Environ Technol. 2012;32:1559 1571.

47. Van Dijk L, Roncken G, Combinatie van biologische afvalwaterzuivering en membraan-technologie [Combination of biological wastewater treatment and membrane technology]. Water J. 1994:41-48. Dutch.

48. Duran M, Speece R. Biodegradability of residual organics in the effluent of anaerobic processes. Environ Technol. 1999;20:597-605. https://doi. org/10.1080/09593332008616854

49. Matheri AN, Sethunya VL, Belaid M, Muzenda E. Analysis of the biogas productivity from dry anaerobic digestion of organic fraction of municipal solid waste. Renew Sustain Energy Rev. 2018;81:2328-2334. https://doi. org/10.1016/j.rser.2017.06.041

50. Matheri AN, Ntuli F, Ngila JC, Seodigeng T, Zvinowanda C, Njenga CK. Quantitative characterization of carbonaceous and lignocellulosic biomass for anaerobic digestion. Renew Sustain Energy Rev. 2018;92:9-16. https:// doi.org/10.1016/j.rser.2018.04.070

51. Matheri AN, Mbohwa C, Ntuli F, Belaid M, Seodigeng T, Ngila JC et al. Waste to energy bio-digester selection and design model for the organic fraction of municipal solid waste. Renew Sustain Energy Rev. 2018;82:1113-1121. https://doi.org/10.1016/j.rser.2017.09.051 